\title{
CAUSES OF LOW ACHIEVEMENT OF UNIVERSITY' STUdents From TheIr PoINTS OF VIEW
}

\author{
Kahtan Ahmed Al-Dahir \\ Professor in the Al-Ahliyya Amman University
}

\begin{abstract}
The aim of the study was to investigate the causes of low achievement from student's points of view for both sexes by various levels and faculties.(106) students took place in the at Al-Ahliyya Amman University $(A A U)$.

A questionnaire was formed and applied, after its validity and reliability were verified. The study resulted in following points :-

The weight of low achievement causes are moderate in four dimensions (Faculty member, students, methods of assessment, course content) while the weight of family factors dimension was high. There are no significant differences at the level of $a \leq 0.05$ in low achievement causes according to gender, the level of study and according to the faculty specialization in three dimensions (Faculty member, methods of assessment, Course content)while there are significant differences at the level of $a \leq 0.05$ in two dimensions (students and family factors ) in behalf of engineering faculty).
\end{abstract}

\section{KEYWORDS}

Faculty member, students, methods of assessment, course content, Family

\section{INTRODUCTION}

The universities are the backbone of the state, which provides the country with all the competencies, and take the initiative in building and improvement the country to what it aspires to. However, countries may differ in how to pay attention to this development according to many variables economic, social, cultural, political and educational, and these variables are still changing, the outlook is not the same in different countries. However, Education is a priority for States because it is the cornerstone of building any nation. But a number of students may suffer from many problems related to various aspects as family problems, the relation with teachers, methods of evaluation and curricula. In this sense, some students may fail to reach the success rate, which is one of the most important problems facing the universities. It is not easy to determine the reasons for this. There are many factors, including students, social, economic and cultural conditions, local environment, emotional stability and social adjustment and recent developments that may negatively affect the student's achievement, especially the Internet and mobile phone, and many parents and teachers complain of this phenomenon, which has become rampant. We all know that the Internet and mobile phone take a very long time, which adversely affect the requirements of academic aspects. Thus, the delay of graduation will increase the burden of families, and will delay in participating in the service of the community in which they live, and this is wasteful the time and money . The reasons are not limited to students and family circumstances, but there are many other reasons related to teacher and his cognitive, social, professional and personal characteristics, the assessment methods used, and the content of the course has an impact. 


\subsection{Research Problem}

The problem of low achievement of students is one of the most important problems facing educational institutions, which may negatively affect student's behavior as they may be relieved of academic delay to undesirable conduct, and one of the most popular theories that explain aggressive behavior is frustration induced aggression ( Al-Dahir, 2015) .As well as its negative impact on the economic, psychological, educational aspects and its affect on the relationship between teachers and students as the teacher is often comfortable with the efficient student who meets the requirements of the university. In addition has negative impact on academic self concept.

Therefore, this study aimed at identifying the reasons leading to the low academic achievement of students, and are there statistically significant differences according to gender ,study stage, specialization variables.

\subsection{Study Questions}

1. What are the reasons for the low academic achievement of students?

2. Are there statistically significant differences at the level of $(0.05 \alpha)$ of the reasons leading to the low academic achievement of the university students according to gender, study stage , specialization(faculty) variables.

\subsection{The Importance of The Study}

1. It is an attempt to shed light on the phenomenon prevalent in university education which is low academic achievement of university students .

2. It stands on the reasons that lead to the decline of university students academically and therefore can be developed strategies that alleviate these problems and access to students to the acceptable level that benefits the students, families, teachers and the whole community.

3. The study may contribute to providing feedback to the university administration and faculties .

4. The results of this study can serve as a theoretical framework for researchers interested in youth problems in general and university education in particular.

\subsection{Previous Studies}

Many studies have been conducted in this field, Talafha (2006) found that the lack of prepreparation of the subjects is the most important personal reasons, and the methods of university teaching, which focus on memorization were the most important educational reasons, while parent authoritarian style was the most important social reasons affected the low cumulative rates of students who have warning. The results also indicated that there is no statistically significant differences between males and females for the most important personal, educational and social reasons.

While Mkumbo \& Amani (2012) found that the reasons of failure and success are due to internal factors are the internal locus of control and emotional stability and self-control. 
Al-Huli and Sheldan (2012) reached that economic reasons is the most negative reasons that affected the continuation of students for their higher studies followed by social reasons and then educational reasons and personal reasons.

-Najimi, Sharifirad, Amini(2013)found the most important reasons leading to failure of students were the curriculums $(065 \pm 4)$, the factors related to the educators $(055 \pm 3.88)$, the learning environment $(062 \pm 3.63)$, the family factors $(3.53 \pm 3.6)$ and socioeconomic factors $(069 \pm 3.45)$.

Muhasna and his colleagues (2013) study showed that the educational reasons are more influential in the low cumulative rates of students followed by social and economic reasons, The personal reasons were the last one.

In this context Tachie \&Chiresha(2013)reached in their study to external factors such as lack of human and material resources, poor teachers, poor teaching methods and some learners attributed their failure to internal factors like laziness, lack of interest and absenteeism While study of Reda\&Mulugeta(2018)reached to student interest, study habit and previous background factors have a significant effect on the academic performance of students. Lastly Tabassum Khan \&Ahmed (2018) revealed in their study the negative impact of facebook addiction on academic achievement .

The previous studies show that there is some similarity between the variables dealt with and the current study. However, the current study was characterized as more comprehensive, as it was dealt with five main dimensions which included the faculty member, student, methods of assessment, course content and family.

The researcher believes that these five variables are the main ones affecting the low academic achievement of students, while most of the previous studies have covered the dimensions of three such as Talafaha (2006), Mkumbo \& Amani, (2013), Tachie \&Chiresha(2013). The current study did not rely only on previous studies and the broad personal experience of the researcher but also asked an open question to a sample of 120 students about the reasons that lead to low achievement.

\section{STUDY POPUlation}

The study population was consisted of (106) students from three basic faculties which represent the largest number and the largest number of low achievers, namely the Faculty of Pharmacy and Medical Sciences and the Faculty of Engineering, including the Department of Architecture and the Faculty of Administrative and Financial Sciences at (AAU).This is what the researcher have collected through the official statistics obtained by the Admissions and Registration Department.

\subsection{Study instrument}

The research required to develop a questionnaire covering all the possible variables that lead to the low academic achievement of students based on previous studies and personal experience in the field of teaching for more than (35) years of the various stages, in addition, an open question to (120) male and female asking them (what are the causes which lead to Low academic achievement? 


\subsubsection{Validity}

The initial questionnaire which consisted of (88) paragraphs were presented to a group of arbitrators, most of them hold the professorship with $\mathrm{PhD}$ from faculties of educational sciences at Amman University, the Arab University of Amman

The paragraphs remained which agreed more than $90 \%$ by the arbitrators and became 70 paragraphs for five dimensions .

\subsubsection{Reliability}

The reliability of the instrument has been verified by calculating the internal consistency coefficients in the half-split and alpha-Cronbach methods. The following table illustrates that

Table (1) illustrates reliability

\begin{tabular}{|l|c|c|}
\hline \multicolumn{1}{|c|}{ Dimensions } & $\begin{array}{c}\text { Alpha- } \\
\text { Cronbach }\end{array}$ & Half-split \\
\hline Faculty member & 0.761 & 0.789 \\
\hline Students & 0.865 & 0.778 \\
\hline Evaluation methods & 0.855 & 0.732 \\
\hline Course content & 0.666 & 0.715 \\
\hline The family & 0.817 & 0.792 \\
\hline total & 0.916 & 0.832 \\
\hline
\end{tabular}

\section{RESULTS AND DisCUSSION}

\subsection{With Regard To The Question: What Are The Reasons That Lead To Low Academic Achievement?}

Table (2) The means and standard deviations of the five variables are arranged in descending order.

\begin{tabular}{|l|c|c|c|c|}
\hline \multicolumn{1}{|c|}{ Dimension } & Number & Means & Standard deviation & Weight \\
\hline Reasons related to Family & 106 & 3.6996 & 1.23978 & High \\
\hline $\begin{array}{l}\text { Reasons related to Faculty } \\
\text { member }\end{array}$ & 106 & 3.1570 & .90194 & moderate \\
\hline Reasons related to students & 106 & 3.1370 & 084962 & moderate \\
\hline Reasons related to content & 106 & 2.9582 & .95444 & moderate \\
\hline $\begin{array}{l}\text { Reasons related to assessment } \\
\text { style }\end{array}$ & 106 & 2.8498 & .777369 & moderate \\
\hline \begin{tabular}{l} 
Total (Five dimensions) \\
\hline
\end{tabular} & 106 & .68092 & 3.1632 & \\
\hline
\end{tabular}

The above table shows that the family dimension is the most important reasons for the low academic achievement, where the weight of this dimension was high while the weight of the other dimensions were moderate with varying degrees. The following table clarifies the paragraphs on this dimension and will be commented on each of these dimensions: 
International Journal of Education (IJE) Vol.7, No.1, March 2019

Table( 3) Means and Standard deviations for reasons related to the faculty member arranged in descending order.

\begin{tabular}{|c|c|c|c|c|c|}
\hline Number & Paragraph & Number & Means & $\begin{array}{l}\text { Standard } \\
\text { deviation }\end{array}$ & Weight \\
\hline 1 & $\begin{array}{l}\text { The faculty member makes fan } \\
\text { of the students. }\end{array}$ & 106 & 4.04362 & 1.23978 & High \\
\hline 2 & $\begin{array}{l}\text { Lack of scientific and practical } \\
\text { experience. }\end{array}$ & 106 & 3.5189 & 1.30370 & moderate \\
\hline 3 & $\begin{array}{l}\text { His voice is monotonous and } \\
\text { does not raise or lower his voice } \\
\text { as required. }\end{array}$ & 106 & 3.2736 & 1.23853 & moderate \\
\hline 4 & $\begin{array}{l}\text { The participation of students in } \\
\text { demonstrating their creative } \\
\text { potential is not sufficiently open. }\end{array}$ & 106 & 3.2642 & 1.31874 & moderate \\
\hline 5 & $\begin{array}{l}\text { Faculty member is not open with } \\
\text { students. }\end{array}$ & 106 & 3.2358 & 1.10023 & moderate \\
\hline 6 & $\begin{array}{l}\text { Does not vary in teaching } \\
\text { methods and techniques. }\end{array}$ & 106 & 3.2358 & 2.02859 & moderate \\
\hline 6 & $\begin{array}{l}\text { The lack of a clear plan for the } \\
\text { Faculty member makes students } \\
\text { do not know what they read. }\end{array}$ & 106 & 3.2358 & 1.28398 & moderate \\
\hline 7 & $\begin{array}{l}\text { The Faculty member style is not } \\
\text { fair in his dealings with students. }\end{array}$ & 106 & 3.2075 & 1.37125 & moderate \\
\hline 8 & $\begin{array}{l}\text { He does not show enthusiasm in } \\
\text { his lecture. }\end{array}$ & 106 & 3.1321 & 1.10476 & moderate \\
\hline 9 & $\begin{array}{l}\text { He does not give students } \\
\text { enough attention to academic } \\
\text { counseling. }\end{array}$ & 106 & 3.0566 & 1.32255 & moderate \\
\hline 10 & $\begin{array}{l}\text { We do not feel the roles of } \\
\text { faculty member which should } \\
\text { assume, like the father, the guide } \\
\text { or the counselor. }\end{array}$ & 106 & 3.0000 & 1.30931 & moderate \\
\hline 11 & $\begin{array}{l}\text { Do not use reinforcement and } \\
\text { encouragement. }\end{array}$ & 106 & 2.9528 & 1.38964 & moderate \\
\hline 12 & $\begin{array}{l}\text { Focuses on the negative aspects } \\
\text { of students more than the } \\
\text { positives. }\end{array}$ & 106 & 2.9434 & 1.32255 & moderate \\
\hline 13 & $\begin{array}{l}\text { Do not use modern teaching } \\
\text { techniques in teaching } \\
\text { adequately and appropriately . }\end{array}$ & 106 & 2.9340 & 1.34709 & mode \\
\hline 14 & $\begin{array}{l}\text { Teaching almost concentrates } \\
\text { on the theoretical aspect without } \\
\text { giving attention to the practical } \\
\text { and applied aspects. }\end{array}$ & 106 & 2.9245 & 1.34305 & moderate \\
\hline 15 & $\begin{array}{l}\text { The weakness of linking the } \\
\text { lecture material with real life } \\
\text { experiences. }\end{array}$ & 106 & 2.8679 & 1.34572 & moderate \\
\hline 16 & $\begin{array}{l}\text { The method of simplification is } \\
\text { not used in the presentation of } \\
\text { the course material. }\end{array}$ & 106 & 2.6887 & 1.26764 & moderate \\
\hline
\end{tabular}

It is clear from the table that these reasons are real reasons that affect students' achievement. The weight of all paragraphs are moderate except one with high weight which is (the faculty member make fun of the students), it was given higher importance as a reason for low achievement. It can 
be said that there is a dynamic relation between the teacher and the course, if the student loves the teacher he will mostly love the course and vice versa. He must also be fair in his dealing with students.

The researcher constantly emphasizes to make the learner in a good psychological position by keeping him away from any cases of failure or frustration. The paragraph (lack of scientific and knowledge expertise) in second place, it should be said that teaching is both science and art, and science alone is not enough to make the learner active, but there is a need for using techniques in how to display the material in an interesting way to draw self-attention, and to show enthusiasm in his lecture to increase their motivation which is leading to effective interaction between the faculty member and students and among students themselves that will open the way for exploiting their potential. The faculty member must use reinforcement of various types and feedback. He is supposed to focus on the positive aspects of the student which is regarded the best way to overcome negative aspects . This strategy is not limited to educational institutions only, but can be used in many places such as family, work, various departments and others. He must also diversify the teaching methods to keep the student away from boredom and keep or raise motivation, and to connect material to life, and he must give attention to the practical and applied aspects that will lead to the students satisfaction.

The faculty member is supposed to control his voice and not be at one tone, but to raise his voice or reduce it according to the importance of the points it raises. Lastly, the faculty member is supposed to facilitate the course material by linking them as much as possible with realistic examples.

Therefore, Non-compliance of the previous points may limit the motivation of students in the effort and perseverance, which leads to low academic achievement. The present study has in some respects been matched by Talafha (2006); Najimi, Sharifirad, Amini and Meftagh(2009); Al-Huli and Chaldean (2012), and Mohsena, et al. (2013).

It is clear that the student is the most important factor leading to the low academic achievement . The weight of all the paragraphs were moderate except one was high weight (lack of selfconfidence) which affects negatively on the exploitation of self-actual potential, as well as affect on student motivation.

The five paragraphs $(2,3,4,5)$ are very important reasons affecting low achievement . The use of psychotropic substances is a real reason for the low achievement of students and this is in line with logic and many studies have proven this, for example, the study (Balsa, Giuliano and French, 2011). The student may stumbled if he is not interested in specialization, since specialization may not be his real choice, but in accordance with the parents' wishes, or his average degree enforced him to specialize, or his financial inability enforced him to choose the specialization, or he may not have a background about specialization.

A paragraph (4) Students may feel frustrated by traditional teaching with limited thinking, without opportunities to ignite internal strengths and potentials, and creative thinking opportunities. The fifth paragraph indicate that university differs from the schools because it includes students from different environments within the country as well as quite a few countries, some of which find it difficult to adapt and meet the requirements of the study. Some may not have enough ambition (mention in 6 paragraph) for effort and perseverance, especially those who live in luxury and wealth. There is a link between ambition and motivation and, if the ambition is weak or absent then motivation is weak or absent (Makamure,2018). Additionally, motivation is very important factor affecting achievement. Many studies have indicated that like, Dickson,2018. 
Table( 4) Means and Standard deviations for reasons related to students arranged in descending order

\begin{tabular}{|c|c|c|c|c|c|}
\hline Number & Paragraph & Number & Means & $\begin{array}{l}\text { Standard } \\
\text { deviation }\end{array}$ & Weight \\
\hline 1 & Lack of self-confidence. & 106 & 3.7170 & 1.32201 & High \\
\hline 2 & Substance abuse. & 106 & 3.5189 & 1.40225 & moderate \\
\hline 3 & Not interested in specialization & 106 & 3.5189 & 1.40903 & moderate \\
\hline 4 & $\begin{array}{l}\text { Lack of opportunities for } \\
\text { students to use their creative } \\
\text { abilities during the study. }\end{array}$ & 106 & 3.4811 & 1.38173 & moderate \\
\hline 5 & $\begin{array}{l}\text { Can not compete with peers } \\
\text { who came from different } \\
\text { educational institutions }\end{array}$ & 106 & 3.4245 & 2.88391 & moderate \\
\hline 6 & Weakness of ambition. & 106 & 3.4245 & $1 / 45372$ & moderate \\
\hline 7 & $\begin{array}{l}\text { Frequent absence of lectures } \\
\text { attendance }\end{array}$ & 106 & 3.3491 & 1.30232 & moderate \\
\hline 8 & Not adaptive to peers. & 106 & 3.3302 & 3.29999 & moderate \\
\hline 9 & $\begin{array}{l}\text { Fun and entertainment are } \\
\text { preferred during the lecture }\end{array}$ & 106 & 3.3019 & 1.41536 & moderate \\
\hline 10 & Not emotionally stable & 106 & 3.2264 & 1.41612 & moderate \\
\hline 11 & Having bad friends. & 106 & 3.1792 & 1.59043 & moderate \\
\hline 12 & He does not like studying & 106 & 3.1321 & 1.30986 & moderate \\
\hline 13 & $\begin{array}{l}\text { Feel ashamed especially with } \\
\text { the opposite sex. }\end{array}$ & 106 & 300660 & 1.48175 & moderate \\
\hline 14 & Lack of motivation & 106 & 3.0566 & 1.39270 & moderate \\
\hline 15 & $\begin{array}{l}\text { Stay up late at night to watch } \\
\text { movies }\end{array}$ & 106 & 3.0556 & 1.36508 & moderate \\
\hline 16 & Insufficient health. & 106 & 2.9810 & 1.32999 & moderate \\
\hline 17 & $\begin{array}{l}\text { The use of mobile phone and } \\
\text { other programs distracted from } \\
\text { the lecture. }\end{array}$ & 106 & 2.9623 & 1.49873 & moderate \\
\hline 18 & $\begin{array}{l}\text { Depending on electronic } \\
\text { registration without benefiting } \\
\text { from academic counseling. }\end{array}$ & 106 & 2.8774 & 1.40545 & moderate \\
\hline 19 & $\begin{array}{l}\text { Lack of sleep for pathological } \\
\text { anxiety. }\end{array}$ & 106 & 2.8208 & 1.39248 & moderate \\
\hline 20 & $\begin{array}{l}\text { Weakness of the student's } \\
\text { ability to remember the } \\
\text { information he studied during } \\
\text { the exam. }\end{array}$ & 106 & 2.7453 & 1.33139 & moderate \\
\hline 21 & $\begin{array}{l}\text { Engage in emotional and } \\
\text { sexual thinking. }\end{array}$ & 106 & 2.6887 & 1.31919 & moderate \\
\hline 22 & $\begin{array}{l}\text { Mentally displaced during the } \\
\text { lecture. }\end{array}$ & 106 & 2.6792 & 1.19958 & moderate \\
\hline 23 & $\begin{array}{l}\text { Unable to study } \\
\text { systematically. }\end{array}$ & 106 & 2.6415 & 1.19673 & moderate \\
\hline
\end{tabular}

The frequent absence of lectures attendance $\backslash$ is a real reason for the decline of academic achievement, this may be due to the luxury and well-being which he lives or his circumstances enforced him to work to meet his needs and family ,or he may responsible of patient in his home, and this is what the researcher touched during his teaching. Also, when a student is not adaptive with his peers or has poor compatibility, whatever their causes will appear to be negative in their achievement. Many studies pointed out the adaptive skills and achievement for example Raines and his colleagues ,2017. 
Some students are not serious to learn ,they prefer fun and entertainment in the lecture Which affect their achievement . Maladjustment is a real reason for low achievement. It affects developmental aspects such as attention ,perception. Thinking. Maladjustment can be linked with paragraph Weakness of the student's ability to remember the information he studied during the exam. Bad friends also have a negative impact on their achievement. They are often drifted into unacceptable socially actions that may be waste of time and may sometimes lead to psychotropic substances. A bad friend can pull a student to do illegal acts. The lack of motivation(as mentioned before) is a real reason for the low achievement of students.

Health inefficiency may be associated with motivation as it negatively affects active participation and effort because the bad health aspect may be Impedes his self-potentials. Another reason, many low-achievers watch for long hours films and videos, especially bad ones, which affects their commitment to permanence, and affect their attention to the lecture because the student does not have enough sleep and be exhausted during the day, lack of sleeping can also cause inability to concentrate, yawning, moodiness, fatigue ,irritability, depressed mood ,difficulty learning new concepts, forgetfulness ,lack of motivation. The lack of sleep may be the result of anxiety, the most serious of which is a negative effect on follow-up and attention. It may hinder the retrieval of information from memory, and we advise students to stay away from excessive anxiety because it inhibits recalling. The preoccupation with emotional and sexual thinking and dissociation of the mind during the lecture, especially negatively affects the materials that need attention and a strong focus toward the teacher such as mathematics, statistics, physics and chemistry. A paragraph that was unable to study in a systematic manner had the least impact on academic achievement. It should be noted that the paragraphs do not have the same affect on achievement. In the same time, there is a link among paragraphs for example $(2,7,8,9,10,11,13$, $14,15,19)$.

Table(5) Means and Standard deviations for reasons related to assessment methods arranged in descending order

\begin{tabular}{|c|c|c|c|c|c|}
\hline Number & Paragraph & Number & Means & $\begin{array}{l}\text { Standard } \\
\text { deviation }\end{array}$ & Weight \\
\hline 1 & $\begin{array}{l}\text { Questions are limited to the } \\
\text { objective type without } \\
\text { Editorial }\end{array}$ & 106 & 3.3208 & 1.19952 & moderate \\
\hline 2 & $\begin{array}{l}\text { The examination questions are } \\
\text { not at the heart of the subject. }\end{array}$ & 106 & 3.2453 & 1.27848 & moderate \\
\hline 3 & $\begin{array}{l}\text { The distribution of marks to } \\
\text { questions is not objective. }\end{array}$ & 106 & 3.0660 & 1.20530 & moderate \\
\hline 4 & $\begin{array}{l}\text { Questions do not cover all the } \\
\text { course. }\end{array}$ & 106 & 3.0377 & 1.21047 & moderate \\
\hline 5 & $\begin{array}{l}\text { The evaluation process does } \\
\text { not pay attention to the creative } \\
\text { aspect. }\end{array}$ & 106 & 2.9623 & 1.25679 & moderate \\
\hline 6 & $\begin{array}{l}\text { Tests are based primarily on } \\
\text { mute remembering. }\end{array}$ & 106 & 2.9151 & 1.20410 & moderate \\
\hline 7 & The tests are not clear. & 106 & 2.9057 & 1.30587 & moderate \\
\hline 8 & $\begin{array}{l}\text { The examinations do not take } \\
\text { into account individual } \\
\text { differences. }\end{array}$ & 106 & 2.8208 & 1.20946 & moderate \\
\hline 9 & Exams difficulty. & 106 & 2.6132 & 1.31345 & moderate \\
\hline 10 & $\begin{array}{l}\text { Assessment is based primarily } \\
\text { on tests. }\end{array}$ & 106 & 2.4717 & 1.32527 & moderate \\
\hline
\end{tabular}


Assessment methods may have an impact on academic achievement but do not reach the level of other dimensions as shown in Table (3) The Paragraph "Questions are limited to the objective type without editorial " depends primarily on the memorization without the questions that open the door to the student to achieve himself through the presentation of self-opinions and the use of creative thinking, and this paragraph is linked to a paragraph "the evaluation process does not pay attention to the creative aspect ", Very important because it is a step that open the way for creative ideas that serve the community rather than memorization Therefore, the researcher believes that the teaching methods that universities follow in general and the means of evaluation need to be re-considered so as to make the student active through non-formal teaching and selfreliance because the best types of learning is self-learning, which leads to the state of creativity and innovation. It is also supposed to take into consideration the creative flame and bright glimpses and assessment is not limited to tests only such as peer and self-assessment in collaborative learning activities.

The evaluation process should take into account individual differences, be clear and precise and do not go beyond the subject. However ,assessment is a vital component of effective teaching practice as teachers and learners cannot avoid giving and getting feedback from any learning activity. Learning assessment is concerned with practices that maximize the value of the feedback process to ensure that learning is optimized. Feedback ranges from the informal(e.g. oral comments given immediately to learners as they think through problems), to more formal(e.g. written feedback, (Cambridge Assessment International Education).

Table( 7) Means and Standard deviations for reasons related to family arranged in descending order

\begin{tabular}{|c|c|c|c|c|c|}
\hline Number & Paragraph & Number & Means & $\begin{array}{l}\text { Standard } \\
\text { deviation }\end{array}$ & Weight \\
\hline 1 & Disintegration of the family & 106 & 4.0377 & 2.05950 & High \\
\hline 2 & $\begin{array}{l}\text { His relationship with family is } \\
\text { not good }\end{array}$ & 106 & 3.9717 & 1.36247 & High \\
\hline 3 & $\begin{array}{l}\text { The quarrels and the constant } \\
\text { fight between the parents }\end{array}$ & 106 & 3.8491 & 1.34372 & High \\
\hline 4 & $\begin{array}{l}\text { The family does not support } \\
\text { the student financially and } \\
\text { morally. }\end{array}$ & 106 & 3.7925 & 1.41903 & High \\
\hline 5 & Divorce parents. & 106 & 3.7264 & 1.57681 & High \\
\hline 6 & Parents compulsory treatment. & 106 & 3.6226 & 1.47650 & moderate \\
\hline 7 & parents Separation. & 106 & 3.6132 & 1.55882 & moderate \\
\hline 8 & $\begin{array}{l}\text { Poor parents' interest in the } \\
\text { future of their children. }\end{array}$ & 106 & 3.5943 & 1.57830 & moderate \\
\hline 9 & $\begin{array}{l}\text { The student does not feel the } \\
\text { family's interest. }\end{array}$ & 106 & 3.5943 & 1.52926 & moderate \\
\hline 10 & Parental disease & 106 & 3.4623 & 1.52549 & moderate \\
\hline 11 & $\begin{array}{l}\text { The family suffers from } \\
\text { economic problems. }\end{array}$ & 106 & 3.4340 & 1.53076 & moderate \\
\hline 12 & Family is not educated. & 106 & 3.10236 & 1.35464 & moderate \\
\hline
\end{tabular}

It is clear from the table that the reasons related to family have taken a higher weight than the other dimensions, which proves that these reasons have a significant impact on academic achievement because the student needs peace of mind and stability so that his mind focuses on learning and achievement and active participation in classroom activities.

The warm and intimate relationship between the parents reflects positively on the relationship with their young adults and the relationship of the adults among them. Therefore, improper family 
conditions such as family disintegration, divorce or separation of parents, parental illness or poor relationship between the student and his family and lack of interest in it or the family's economic suffering all have an impact on achievement. There are many studies that have shown the influence of family factors on achievement such as Hill \& Tyson (2009)who analyzed 50 studies in this regard and showing the close relationship between family factors and achievement. Many other studies have shown the relationship between family factors and achievement,like,Mathoni,2013;Doly ,2018. The results of this study have in some respects been consistent with Najimi, Sharifirad, Amini and Meftagh(2009); Trchie\& hiresha(2013).

\subsection{With Regard To: Are There Differences According To Gender Variable}

Table (8) Differences between students according to gender variable

\begin{tabular}{|c|c|c|c|c|c|c|c|}
\hline Dimension & Category & Number & Means & $\begin{array}{l}\text { Standard } \\
\text { deviation }\end{array}$ & df & T value & Sig \\
\hline $\begin{array}{l}\text { Faculty } \\
\text { member }\end{array}$ & $\begin{array}{c}\text { Males } \\
\text { Females }\end{array}$ & $\begin{array}{l}77 \\
29\end{array}$ & $\begin{array}{l}3.0794 \\
3.3631\end{array}$ & $\begin{array}{l}.86746 \\
.97346\end{array}$ & 104 & 1.45 & 607. \\
\hline Students & $\begin{array}{c}\text { Males } \\
\text { Females }\end{array}$ & $\begin{array}{l}77 \\
29\end{array}$ & $\begin{array}{l}3.1423 \\
3.1229\end{array}$ & $\begin{array}{l}.84489 \\
.87699\end{array}$ & 104 & .104 & .626 \\
\hline $\begin{array}{c}\text { Assessment } \\
\text { methods }\end{array}$ & $\begin{array}{c}\text { Males } \\
\text { Females }\end{array}$ & $\begin{array}{l}77 \\
29\end{array}$ & $\begin{array}{l}2.7511 \\
3.1121\end{array}$ & $\begin{array}{l}.74847 \\
.80650\end{array}$ & 104 & 2.179 & .306 \\
\hline $\begin{array}{l}\text { Course } \\
\text { content }\end{array}$ & $\begin{array}{c}\text { Males } \\
\text { Females }\end{array}$ & $\begin{array}{l}77 \\
29\end{array}$ & $\begin{array}{l}2.8757 \\
3.1773\end{array}$ & $\begin{array}{l}.96177 \\
.87952\end{array}$ & 104 & 1.472 & .937 \\
\hline Family & $\begin{array}{c}\text { Males } \\
\text { Females }\end{array}$ & $\begin{array}{l}77 \\
29\end{array}$ & $\begin{array}{l}3.6907 \\
3.7241\end{array}$ & $\begin{array}{l}1.26108 \\
1.20273\end{array}$ & 104 & .123 & .900 \\
\hline Total & $\begin{array}{c}\text { Males } \\
\text { Females }\end{array}$ & $\begin{array}{l}77 \\
29\end{array}$ & $\begin{array}{l}3.1185 \\
3.2793\end{array}$ & $\begin{array}{l}.64334 \\
.77205\end{array}$ & 104 & 1.078 & .183 \\
\hline
\end{tabular}

There were no statistically significant differences according to the gender variable in all dimensions. This indicates the convergence of views, especially since women played a large role in society in light of globalization, which had a great role in raising women's awareness of their rights. They participated in most areas of life, as well as university life does not differentiate between the males and females, each of them have rights and duties do not differ. Therefore, the view of the previous variables was converged. The results of the present study were consistent with the results of the study of Huli and Shaldan (2012).,Yagan wali,Ali and Bufarafa,(2015) and Talafaha (2006), while there were differences according to the gender variable in the educational dimension in the study of Muhasna and his colleagues (2013). 
International Journal of Education (IJE) Vol.7, No.1, March 2019

\subsection{With Regard To : Are There Differences According To The Variable Of The Study Stage.}

Table (9) The mean and standard deviations according to study stage variable

\begin{tabular}{|c|c|c|c|c|}
\hline dimension & the study stage & Number & Means & Standard deviation \\
\hline \multirow{4}{*}{ Faculty member } & Second & 23 & 3.1662 & 1,09571 \\
\hline & Third & 32 & 3.2224 & .99991 \\
\hline & forth & 51 & 3.1119 & .74520 \\
\hline & total & 106 & 3.1570 & .90194 \\
\hline \multirow[t]{4}{*}{ Students } & Second & 23 & 2.9887 & .89683 \\
\hline & Third & 32 & 3.2595 & .68260 \\
\hline & fourth & 51 & 3.1270 & .92374 \\
\hline & total & 106 & 3.1370 & .84962 \\
\hline \multirow{4}{*}{$\begin{array}{l}\text { Assessment } \\
\text { methods }\end{array}$} & Second & 23 & 2.8225 & .78347 \\
\hline & Third & 32 & 2.9271 & .82841 \\
\hline & fourth & 51 & 2.8137 & .74565 \\
\hline & total & 106 & 2.8498 & .77369 \\
\hline \multirow[t]{4}{*}{ Course content } & Second & 23 & 2.6087 & .90168 \\
\hline & Third & 32 & 3.1830 & .84573 \\
\hline & fourth & 51 & 2.9748 & .99374 \\
\hline & total & 106 & 2.9582 & .94555 \\
\hline \multirow[t]{4}{*}{ Family } & Second & 23 & 3.4229 & 1.42411 \\
\hline & Third & 32 & 3.9858 & .86252 \\
\hline & forth & 51 & 3.6453 & 1.38388 \\
\hline & total & 106 & 3.6998 & 1.23978 \\
\hline \multirow[t]{4}{*}{ Total } & Second & 23 & 3.0335 & .70849 \\
\hline & Third & 32 & 3.3000 & .60543 \\
\hline & fourth & 51 & 3.1359 & .71068 \\
\hline & total & 106 & 3.1832 & .68092 \\
\hline
\end{tabular}

The table above shows that the means in the first dimension are almost convergent, but the means in the family dimension is higher than the other dimensions. The total score (3.6996) is of high weight and the lowest is related to course content (2.9582) The statistical significance can be determined by analyzing the co-variance .

Table (10) one way -variance analysis of the variables of the study stage

\begin{tabular}{|c|c|c|c|c|c|c|}
\hline Variables & Source & $\begin{array}{l}\text { Some of } \\
\text { squares }\end{array}$ & df & $\begin{array}{c}\text { Mean } \\
\text { square }\end{array}$ & $\mathbf{F}$ & Sig \\
\hline $\begin{array}{l}\text { Faculty } \\
\text { member }\end{array}$ & Within groups & 85.174 & 103 & 827 & & \\
\hline \multirow[t]{3}{*}{ Students } & Between groups & 991 & 2 & 496 & 683 & 508 \\
\hline & Within groups & 74.804 & 103 & .726 & & \\
\hline & Total & 75795 & 105 & & & \\
\hline \multirow{2}{*}{$\begin{array}{l}\text { Assessment } \\
\text { methods }\end{array}$} & Within groups & 62.578 & 103 & 608 & & \\
\hline & Total & 62.853 & 105 & & & \\
\hline \multirow[t]{3}{*}{$\begin{array}{l}\text { Course } \\
\text { content }\end{array}$} & Between groups & 4.441 & 2 & 2.221 & 2.557 & .082 \\
\hline & Within groups & 89.435 & 103 & .868 & & \\
\hline & Total & 93.876 & 105 & & & \\
\hline Family & Between groups & 4.532 & 2 & 2.268 & 1.488 & 231 \\
\hline Total & Total & 48.683 & 105 & & & \\
\hline
\end{tabular}


The results show that there are no statistically significant differences on all dimensions, which, the perception of the reasons for the low academic achievement was close to the three stages (second, third and fourth), especially in the Semester system which is different from annual system ,as it may three stages available in the same course in the Semester system.

\subsection{With Regard To : Are There Differences According To The Specialization Variable .}

Table (11) means and standard deviations according to the specialization variable

\begin{tabular}{|c|c|c|c|c|}
\hline Dimension & Specialization(faculty) & Number & Means & $\begin{array}{l}\text { Standard } \\
\text { deviation }\end{array}$ \\
\hline \multirow{4}{*}{$\begin{array}{l}\text { Faculty } \\
\text { member }\end{array}$} & Pharmacy & 41 & 3.3286 & 1,06396 \\
\hline & Engineering & 35 & 3.0739 & .68960 \\
\hline & Admin\& Financial Sciences & 30 & 3.0196 & .87007 \\
\hline & Total & 106 & 3.1570 & .90194 \\
\hline \multirow[t]{4}{*}{ Students } & Pharmacy & 41 & 3.0979 & .84887 \\
\hline & Engineering & 35 & 3.4484 & .81809 \\
\hline & $\begin{array}{l}\text { Administrative \& Financial } \\
\text { Sciences }\end{array}$ & 30 & 2.8275 & .78531 \\
\hline & Total & 106 & 3.1370 & .08252 \\
\hline \multirow{4}{*}{$\begin{array}{l}\text { Assessment } \\
\text { methods }\end{array}$} & Pharmacy & 41 & 2.8516 & .12057 \\
\hline & Engineering & 35 & 2.9595 & .11353 \\
\hline & Administrative Financial Sciences & 30 & 2.7198 & .16168 \\
\hline & Total & 106 & 2.8498 & .07515 \\
\hline \multirow{4}{*}{$\begin{array}{l}\text { Course } \\
\text { content }\end{array}$} & Pharmacy & 41 & 2.9756 & .12825 \\
\hline & Engineering & 35 & 3.0490 & .13533 \\
\hline & $\begin{array}{l}\text { Administrative \& Financial } \\
\text { Sciences }\end{array}$ & 30 & 2.8286 & .22566 \\
\hline & Total & 106 & 2.9582 & .09184 \\
\hline \multirow[t]{4}{*}{ Family } & Pharmacy & 41 & 3.5477 & .19176 \\
\hline & Engineering & 35 & 4.1584 & .19524 \\
\hline & $\begin{array}{l}\text { Administrative \& Financial } \\
\text { Sciences }\end{array}$ & 30 & 3.3727 & .22541 \\
\hline & Total & 106 & 3.6998 & .12042 \\
\hline \multirow[t]{4}{*}{ Total } & Pharmacy & 41 & 3.1700 & .11242 \\
\hline & Engineering & 35 & 3.3453 & .09289 \\
\hline & $\begin{array}{l}\text { Administrative \& Financial } \\
\text { Sciences }\end{array}$ & 30 & 2.9414 & .13152 \\
\hline & Total & 106 & 3.1632 & .06614 \\
\hline
\end{tabular}

It is clear from the table in general that the results were close except in the dimensions of students and the family. The mean of the Faculty of Engineering (3.4484) was higher than the means of the Faculty of Pharmacy and Medical Sciences (3.0979) and the Faculty of Administrative and Financial Sciences (2.8275).the same in regard to family ,the mean of Engineering faculty was (4.1584) while the Faculty of Pharmacy and Medical Sciences (3.5477) and the Faculty of Administrative and Financial Sciences (3.3727). The following is a one way -variance analysis test to determine the significance of differences. 
International Journal of Education (IJE) Vol.7, No.1, March 2019

Table (12) one way -variance analysis indicate the differences in the response of students according to the variable of specialization (Faculty).

\begin{tabular}{|c|c|c|c|c|c|c|}
\hline Variables & Source & $\begin{array}{l}\text { Some of } \\
\text { squares }\end{array}$ & df & Mean square & $\mathbf{F}$ & Sig \\
\hline $\begin{array}{l}\text { Faculty } \\
\text { member }\end{array}$ & $\begin{array}{l}\text { Between } \\
\text { groups }\end{array}$ & 2.014 & 2 & 1.007 & 1.244 & .293 \\
\hline & Within groups & 83.402 & 103 & .810 & & \\
\hline & Total & 85.417 & 105 & & & \\
\hline Students & $\begin{array}{c}\text { Between } \\
\text { groups }\end{array}$ & 6.332 & 2 & 3.166 & 4.694 & .011 \\
\hline & Within groups & 69.463 & 103 & .674 & & \\
\hline & Total & 75.795 & 105 & & & \\
\hline $\begin{array}{l}\text { Assessment } \\
\text { methods }\end{array}$ & $\begin{array}{c}\text { Between } \\
\text { groups }\end{array}$ & .931 & 2 & .446 & .775 & .464 \\
\hline & Within groups & 61.922 & 103 & .601 & & \\
\hline & Total & 62.853 & 105 & & & \\
\hline $\begin{array}{l}\text { Course } \\
\text { content }\end{array}$ & $\begin{array}{l}\text { Between } \\
\text { groups }\end{array}$ & .805 & 2 & .402 & .445 & .082 \\
\hline & Within groups & 93.071 & 103 & .904 & & \\
\hline & Total & 93.876 & 105 & & & \\
\hline Family & $\begin{array}{c}\text { Between } \\
\text { groups }\end{array}$ & 11.520 & 2 & 5.760 & 3.959 & .022 \\
\hline & Within groups & 149.871 & 103 & 1.445 & & \\
\hline & Total & 161.391 & 105 & & & \\
\hline Total & $\begin{array}{l}\text { Between } \\
\text { groups }\end{array}$ & 2.638 & 2 & 1.319 & 2.951 & .057 \\
\hline & Within groups & 46.045 & 103 & .447 & & \\
\hline & Total & 48.683 & 105 & & & \\
\hline
\end{tabular}

The table shows that there were no statistically significant differences in the three dimensions (faculty member, evaluation methods and course content), while significant differences were observed at $(0.05 \alpha \alpha)$ in the students and family dimensions. The family, in all its variants, is the basis for the formation of the basic features of the personality, which greatly affect the academic self concept. It is the first environment for emotional and social learning, so it affects the educational achievement more than the other variables .

To find out the significance of the variance of any faculty ,scheffe test was used

Table (13) Scheffe test to determine the significance differences

\begin{tabular}{|c|c|c|c|c|c|}
\hline Dimension & Faculties & $\begin{array}{c}\text { Means } \\
\text { differences }\end{array}$ & Sig & $\begin{array}{l}\text { Low } \\
\text { value }\end{array}$ & $\begin{array}{l}\text { Upper } \\
\text { value }\end{array}$ \\
\hline \multirow{6}{*}{ Students } & Engineering Pharmacy & .35089 & .184 & .8203 & .1185 \\
\hline & $\begin{array}{c}\text { Administrative \& Financial } \\
\text { Sciences }\end{array}$ & .27002 & .395 & .2200 & .7601 \\
\hline & $\begin{array}{ll}\text { Pharmacy } & \text { Engineering }\end{array}$ & .35089 & .184 & .1185 & .8203 \\
\hline & Administrative and Financial & 62091 & .012 & .1134 & 1.1284 \\
\hline & $\begin{array}{ll}\text { Pharmacy } & \text { Administrative \& }\end{array}$ & .27002 & .395 & .7601 & .2200 \\
\hline & Engineering & 62091 & .012 & 1.1284 & .1134 \\
\hline \multirow{6}{*}{ Family } & Engineering & .61077 & .094 & 1.3003 & .0787 \\
\hline & $\begin{array}{c}\text { Administrative and Financial } \\
\text { Sciences }\end{array}$ & .17494 & .834 & .5449 & .8984 \\
\hline & $\begin{array}{ll}\text { Pharmacy } & \text { Engineering }\end{array}$ & 61077 & .094 & .0787 & 1.3003 \\
\hline & Administrative \& Financial & .78571 & .036 & .0403 & 1.5312 \\
\hline & Pharmacy $\quad$ Administrative \& & .17494 & .843 & .8948 & .5449 \\
\hline & Engineering & .78571 & .036 & 1.5312 & .0403 \\
\hline
\end{tabular}


The table shows that the differences between the three faculties are in favor of the Faculty of Engineering in both the students and the family dimensions, where the significance was in dimension of the students (.012) and in the dimension of the family (.036). This means that the students of the Faculty of Engineering responded to reasons related to students' as actual reasons leading to low academic achievement. It may be said that creative thinking is more clear in the Faculty of Engineering, and this requires creating a positive atmosphere conducive to creative thinking so the reasons related to the student and family may affect them more than others.

\section{RECOMMENDATIONS}

1. Diversity in evaluation methods to take into account individual differences and creative aspects of students.

2. The focus of the faculty member on the positive aspects of students and keep them away from any kind of failure and frustration and ridicule.

3. The faculty member supposed to play his role as a leader, counselor and educator by opening the door wide to students to vent their various problems because the faculty member represents alternative father in the university

4. Use different educational methods and techniques and modern educational Technologies.

5. Linking the material to practical life as much as possible.

6. Counseling students is very necessary according to the guidance plan.

7. Urge students to take care of their health and take adequate sleep to be ready to prepare for comprehending the lectures.

8. Provide students with additional references other than the book test to benefit more and remove what is unclear.

9. Mass media must take it role to urge families to be collaborated and stay away from any case of separation, quarrel and hatred because of the negative impact on the effort and effectiveness of their students in educational institutions.

\section{REFERENCES}

[1] Al-Dahir ,K.A.(2012). Self concept between theoretical and application. Amman: Dar Wael.

[2] Al-Dahir ,K.A.(2015). Introduction to special education , Amman :Dar Wael .

[3] Al-Huli, A. A and Sheldan, F. K. (2012). The causes of educational waste among post graduate students at the Islamic University in Gaza and ways of treatment. The Second Arab International Conference for Quality Assurance of Higher Education.

[4] Balsa,A., Giuliano.L. and French,M. (2011). The effects of alcohol use on academic achievement in high school . Econ Educ Rev. 2011 , 30(1): 1-15.23

[5] Cambridge Assessment International Education : Assessment for Learning. https://www.cambridgeinternational.org/Images/271179-assessment-for-learning.pdf.

[6] Dickson,O.(2018).effect of extrinsic motivation on secondary school students academic achievement in social studies . International Journal of Education (IJE), 6(3),1-7. 
[7] Doli,L.(2018).The impact of home environment factors on academic achievement of adolescents . Journal of Arts, Science \& Commerce .4(1):137-147.

[8] Hill, N.E., \& Tyson, D.F. (2009). Parental Involvement in Middle School: A MetaAnalytic Assessment of the Strategies That Promote Achievement. Developmental Psychology, 45(3), 740763.

[9] Makamure,C.(2018). Evoking motivation for achievement in O level mathematics in Zimbabwe. International Journal of Education (IJE) Vol.6, No.4, 13-21

[10] Mkumbo , Kitila,A.K.,\& Amani ,Jacueline .(2012). Perceived university student' attribution of their academic success and failure. Asian Social Science, Vol.8, No.7

[11] Muhasna,A.,Alzubi,Z,.Muhansa,A.,Betaina,U.,and Alzubi,A.(2013). The reasons for the decline in the cumulative average of the students of the Hashemite University from students' point of view Derasat, Educational Sciences, 40: 1 .

[12] Muthoni,K.L.(2013).Relationship between family background and academic performance of secondary schools students: A case of Siakago Divion, Mbeere, North District, Kenya.Master of Art:The University of Nairobi.

[13] Najimi,A ., Sharifirad,G., Amini,M.M and Meftagh,S.D .(2013). Academic failure and students' viewpoint: The influence of individual, internal and external organizational factors. Journal of Education and Health Promotion. 2: 22.

[14] Raines,T.S., Gordon,M.,Harrel -Williams,L.,Diliborto,R.A.,\&Parke,E.M.(2017). Adaptive skills and academic achievement in Latino students .Journal of Applied School Psychology,33(4)245-260

[15] Reda,H\&Mulugeta.G.(2018).Investigation the causes of students less academic performance in engineering college of Debre Berhan University .American Journal of Theoretical and Applied Statistics ,7(3):126-131 .

[16] TabassumKhan,N.,\&Ahmed,S.(2018). Impact of facebook addiction on student academic performance .Research in Medical and Engineering Sciences,5,2

[17] Talafaha, F. (2006). Reasons for the low cumulative rates of warning students: field diagnostic study on a sample of students of the University of Mu'tah. University of Damascus Journal ,22:2

[18] Trchie,S.A.,\& Chiresha,R.(2013). High failure rate in mathematics examinations in rural senior secondary schools in Mthatha District, Eastern Cape:Learners attributions Stud TribesTribals,11(1):67-73 .

[19] Yagan wali,U.G.,Ali,H.K., and Bufarafa,M.W.(2015).Gnder ddifference in studend's academic performance in college of education in Borno,Nigeria: Implication for counseling. Journal of Education and Practice,6(32):107-114.

\section{AUTHORS}

Kahtan Ahmed Al-Dahir is a Professor in special education (college of Art and Sciences ,Department of Special Education and College of Pharmacy and Medical sciences ,Department of Audiology and Speech Pathology ) at AlAhliyya Amman university .I have many books and articles in the field of special education and educational psychology . I taught many subjects for the stages of bachelor's, master's and doctoral degrees. and supervised and discussed many Masters and PhD students.

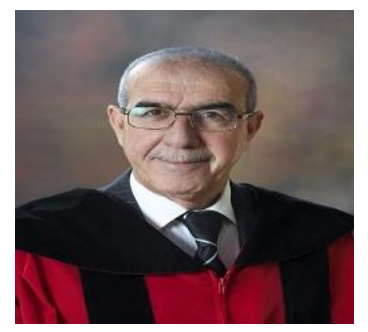

